\title{
Intramammary infusion of lipopolysaccharide promotes inflammation and alters endometrial gene expression in lactating Holstein cows
}

\author{
C. C. Campos, ${ }^{*} \dagger$ I. Hartling, ${ }^{*}$ M. Kaur, ${ }^{*}$ A. C. C. Fernandes, ${ }^{*}$ R. M. Santos, $\dagger$ and R. L. A. Cerri ${ }^{* 1}$ \\ *Applied Animal Biology, Faculty of Land and Food Systems, University of British Columbia, Vancouver, V6T 1Z4 BC, Canada \\ †School of Veterinary Medicine, Federal University of Uberlandia, Uberlandia 38400-902, Brazil
}

\begin{abstract}
The objective of the current study was to evaluate the effects of 2 intramammary infusions of lipopolysaccharide (LPS) on inflammatory and reproductive parameters and endometrial gene expression of lactating Holstein cows. At $35 \pm 7 \mathrm{~d}$ in milk, 20 cows were submitted to a Double Ovsynch program and randomly assigned to control $(\mathrm{n}=11)$ and LPS $(\mathrm{n}=9)$ treatments. Cows from the LPS treatment received 2 intramammary infusions of $25 \mu \mathrm{g}$ of LPS after morning milking on d 5 and 10 post-AI, whereas control cows were infused with only saline. Blood samples were taken and ultrasound scanning of the ovaries was performed during the entire study before and after AI to determine haptoglobin, tumor necrosis factor- $\alpha$, and progesterone concentrations as well as response to the hormonal protocol and corpus luteum diameter. Milk yield was evaluated and samples were taken for somatic cell count at 0, 10, 24, 34 , and $96 \mathrm{~h}$ relative to each infusion. Rumen-reticular temperature was recorded using a rumen-reticular bolus logger and summarized hourly. On d 15 post-AI, uterine flushing for conceptus recovery and endometrial biopsies were performed. Samples of endometrium from cows with positive embryo recovery (control $=$ 5 ; LPS $=6$ ) were submitted to mRNA extraction and quantitative reverse-transcription PCR analysis of 96 target genes. Haptoglobin concentrations in plasma were greater for LPS treatment (control $=0.24 \pm 0.07$, LPS $=0.89 \pm 0.06$ optical density), but tumor necrosis factor- $\alpha$ concentrations were similar (control $=0.67 \pm$ 0.11 , LPS $=0.46 \pm 0.11 \mathrm{ng} / \mathrm{mL}$ ) between treatments. Lipopolysaccharide reduced milk yield after treatment (control $=34.3 \pm 1.5$, LPS $=29.4 \pm 1.6 \mathrm{~kg} / \mathrm{d}$ ), whereas somatic cell count $(\log )$ was greater in LPS-treated cows until $34 \mathrm{~h}$ after infusions (control $=2.3 \pm 0.1$, LPS $=3.3 \pm 0.1$ cells $/ \mathrm{mL}$ of milk). Rumen-reticular
\end{abstract}

Received January 4, 2018.

Accepted June 6, 2018.

${ }^{1}$ Corresponding author: ronaldo.cerri@ubc.ca temperature of LPS cows was elevated between 5 and $10 \mathrm{~h}$ after each infusion compared with control cows $\left(\right.$ control $=39.5 \pm 0.1$, LPS $\left.=40.1 \pm 0.1^{\circ} \mathrm{C}\right)$. Progesterone concentration after AI was unaffected by treatment or pregnancy status as well as corpus luteum diameter and conceptus length on d 15. Lipopolysaccharide treatment altered the expression of 13 key genes in the endometrium (mostly upregulated), whereas another 17 tended to be modulated. Modified gene expression included genes related to immune response $($ PTX $3=$ 2.34-fold increase; $I L 6=3.42$-fold increase; and TCN1 $=2.52$-fold increase), adhesion molecules (CADM3 $=1.93$-fold increase; $M M P 19=1.49$-fold increase; $E M M P R I N=1.20$-fold increase $\quad S E L L=1.91$-fold increase), Wnt signaling pathway (WNT2, FZD4, and $F Z D 7$, all $<1.5$-fold increase), and interferon-stimulated genes $(B M P 15=0.27$-fold decrease; ISG15 $=2.17$-fold increase, and $M X 2=2.23$-fold increase). In summary, intramammary infusions of LPS were able to trigger an inflammatory response with no effect on corpus luteum diameter and concentration of progesterone in plasma. However, a limited but important set of modulations in the endometrium gene expression at d 15 of gestation was found.

Key words: endometrium, gene expression, inflammation, lipopolysaccharide, mastitis

\section{INTRODUCTION}

Many physiologic and endocrine changes that occur during the transition period of dairy cows contribute to increase the risk of postpartum diseases (Cai et al., 1994). After calving, feed intake remains low and is unable to supply energy for milk production, resulting in negative energy balance, which decreases immunological competence (Grummer et al., 2004). It is known that occurrence of postpartum diseases such as mastitis impairs productive and reproductive performance of dairy cows (Schrick et al., 2001; Santos et al., 2004; Hertl et al., 2010). However, the biological pathways by which inflammation affects fertility are multifactorial and involve different and complex mechanisms that 
are not yet fully understood (Bromfield et al., 2015; Ribeiro et al., 2016).

Acute clinical mastitis is often caused by gram-negative bacteria, which are widely spread in modern dairy cow operations (Sheldon et al., 2010). During bacterial replication or death, LPS is released from the outer membrane of gram-negative bacteria, such as Escherichia coli, and is majorly responsible for its pathogenicity. The endotoxin has a high potential to induce an inflammatory response by the host (Akira et al., 2006), which leads to the production of a variety of acute phase proteins and cytokines as well as tissue damage. Skarnes and Harper (1972) first showed evidence of endometrial $\mathrm{PGF}_{2 \alpha}$ release after LPS parenteral administration in rodents. Jackson et al. (1990) demonstrated that intravenous infusion of LPS resulted in an increase of serum concentration of $\mathrm{PGF}_{2 \alpha}$ in lactating dairy cows. Bacterial endotoxin release associated with inflammatory mediators produced by the host may cause local and systemic effects that reduce reproductive performance of dairy cows. As an example, tumor necrosis factor (TNF)- $\alpha$ is an important cytokine synthetized during a gram-negative mastitis case (Sordillo et al., 1995). Tumor necrosis factor- $\alpha$ induces premature release of $\mathrm{PGF}_{2 \alpha}$ from the endometrium (Miyamoto et al., 2000), resulting in luteolysis and a gradual decrease of progesterone levels that are incompatible with gestation (Giri et al., 1990; Skarzynski et al., 2000; Hansen et al., 2004). Recently, Lüttgenau et al. (2016) reported that repeated intrauterine infusions of LPS at the onset of the estrous cycle promoted premature luteolysis and altered endometrial and corpus luteum (CL) gene expression. Therefore, the negative effect of infection on reproductive tract functionality is probably due to a direct effect of endotoxin added to indirect effects of inflammatory mediators.

Reproductive and nonreproductive diseases promote immune and inflammatory responses that may compromise ovulation (Suzuki et al., 2001; Lavon et al., 2008), fertilization (Ribeiro et al., 2016), embryonic development and survival (Soto et al., 2003; Hansen et al., 2004), hypothalamic-pituitary-gonadal axis functionality (Herman et al., 2010), ovarian follicular growth and steroidogenesis (Herath et al., 2007), oocyte competence (Roth et al., 2013), and uterine environment for pregnancy maintenance (Bromfield et al., 2015). The modifications in the endometrium environment in the preimplantation period have been described (Forde et al., 2011). However, the modifications caused by endotoxins from bacterial origin or other molecules that can trigger inflammation and an active immune response in this endometrium environment are unclear and deserve further work. The objective of the current study was to evaluate the effects of 2 intramammary infusions of LPS on inflammatory and reproductive parameters during the first $15 \mathrm{~d}$ of gestation and endometrial gene expression at d 15 of gestation in lactating Holstein cows. We hypothesized that LPS intramammary challenge alters gene expression in the endometrium during the onset of embryonic development before implantation takes place.

\section{MATERIALS AND METHODS}

The Canadian Council of Animal Care from the University of British Columbia (protocol no. A15-0089) approved all animal procedures conducted during this experiment. This experiment was performed at the University of British Columbia's Dairy Education and Research Centre in Agassiz, British Columbia, Canada $\left(49^{\circ} 14^{\prime} 35^{\prime \prime} \mathrm{N}, 121^{\circ} 45^{\prime} 37^{\prime \prime} \mathrm{W}\right)$.

\section{Animals, Housing, and Nutrition}

Multiparous (lactation $=2-8 ; \mathrm{n}=13$ ) and primiparous $(\mathrm{n}=11)$ Holstein lactating dairy cows with daily average of $37.0 \mathrm{~kg}$ of milk/cow and BCS varying between 2.50 and 3.25 (scale of 1 to 5 proposed by Edmonson et al., 1989) were enrolled in the experiment at $35 \pm 7$ DIM. Cows were housed in sand-bedded freestalls with concrete flooring and without cooling methods and milked twice daily at 0500 and $1500 \mathrm{~h}$. Water and TMR were available for ad libitum intake, and fresh TMR was placed in the trough twice daily at approximately 0700 and $1600 \mathrm{~h}$. The diet comprised corn and ryegrass silages formulated in accordance with NRC (2001) recommendations.

\section{Ovulation Synchronization}

Before the initiation of the synchronization protocols, all cows were checked for health and reproductive disorders by physical examination of the digestive, reproductive, and mammary systems 3 times/wk during the first 3 wk postpartum and were observed daily for mastitis diagnosis during the whole experimental period. Only clinically healthy cows with no diagnosis of dystocia or digestive disorders were included in the study. A modified Double Ovsynch program was used to synchronize the ovulation of the cows. Presynchronization with the first Ovsynch protocol was initiated $(\mathrm{d}-29)$ with an i.m. injection of $\mathrm{GnRH}(100 \mu \mathrm{g}$ of gonadorelin acetate; Fertiline, Vétoquinol, Lavaltrie, QC, Canada) at $35 \pm 7$ $\mathrm{d}$ after parturition followed $7 \mathrm{~d}$ later $(\mathrm{d}-22)$ by an i.m. injection of $\mathrm{PGF}_{2 \alpha}(500 \mu \mathrm{g}$ of cloprostenol; Estrumate, Merck, Kirkland, QC, Canada). Two days after $\mathrm{PGF}_{2 \alpha}$ 
injection (d -20), another i.m. injection of GnRH (100 $\mu \mathrm{g})$ was administered. At $10 \mathrm{~d}$ after the second $\mathrm{GnRH}$ (d -10), the second Ovsynch protocol for ovulation synchronization was initiated by administering $100 \mu \mathrm{g}$ of GnRH i.m. and an intravaginal insert containing $1.38 \mathrm{~g}$ of progesterone (CIDR 1380; Easi-Breed, Zoetis Animal Health, Kirkland, QC, Canada) for 7 d. Cows received an injection of $\mathrm{PGF}_{2 \alpha}(500 \mu \mathrm{g})$ at the time of CIDR withdrawal $(\mathrm{d}-3)$ and a second $\mathrm{PGF}_{2 \alpha}(500 \mu \mathrm{g})$ i.m. injection 12 h later. Finally, GnRH $(100 \mu \mathrm{g})$ was injected $56 \mathrm{~h}$ after the $\mathrm{PGF}_{2 \alpha}$ injection $(\mathrm{d}-1)$, and cows underwent timed AI $12 \mathrm{~h}$ later (d 0; Figure 1). Semen from 2 different Holstein bulls was randomly assigned to cows from the 2 treatments. Ovarian response to hormonal treatments was followed by transrectal real-time ultrasonography (Ibex Pro; EI Medical Imaging, Loveland, $\mathrm{CO}$ ) equipped with a $7.5 \mathrm{-MHz}$ linear transducer (Figure 1). The ultrasound examinations were performed after each injection and $2 \mathrm{~d}$ after each GnRH injection to verify ovulation and CL diameter over time (growth after ovulation and regression after $\mathrm{PGF}_{2 \alpha}$ injections) and on $\mathrm{d} 5,10$, and 15 post-AI to certify final CL diameter and premature CL regression.

\section{Treatments}

The rear left teat was established as a pattern for all infusions and milk sample collection. Before treatment onset (d 0), milk samples from each cow were collected for microbiological analysis and SCC to ensure that cows with clinical or subclinical mastitis were not enrolled in the experiment. As a criterion, milk samples for culture should not have any type of bacterial growth, and the threshold for SCC was lower than 200,000 cells/mL of milk. Furthermore, to ensure that the other teats were also free of inflammation, the California Mastitis Test was performed $1 \mathrm{~d}$ before first infusion (d 5 ).

Animals were randomly assigned to 2 treatments. In the LPS treatment $(n=9)$, cows received 2 intramammary infusions of LPS on d 5 and 10, and in the control treatment $(n=11)$, cows were infused twice on $d 5$ and 10 with saline. Infusions for the LPS treatment were prepared by diluting $25 \mu \mathrm{g}$ of LPS from E. coli strain 0111:B4 (Sigma-Aldrich, St. Louis, MO) in $10 \mathrm{~mL}$ of saline solution, and infusions for the control treatment were prepared with $10 \mathrm{~mL}$ of saline solution. The infusions were homogenized using a digital vortex mixer for $1 \mathrm{~min}$ and then transferred to syringes identified with the cows' identification numbers on the day before treatments and kept at $4^{\circ} \mathrm{C}$ until administration.

Infusions were performed twice per cow, at d 5 and 10 (Figure 1), during the morning milking immediately after automatic extraction of the milking machine units. The rear left teat was cleaned with $70 \%$ alcohol swabs, and the solution was slowly infused into the teat using a cannula attached to the syringe. Then, the teat was held closed to avoid reflux while it was massaged to spread the liquid inside the gland. Postdipping was performed at the end of infusion.

\section{Milk Sampling for SCC}

Milk samples from the rear left teat were collected at $0,10,24,34$, and $96 \mathrm{~h}$ relative to each infusion for

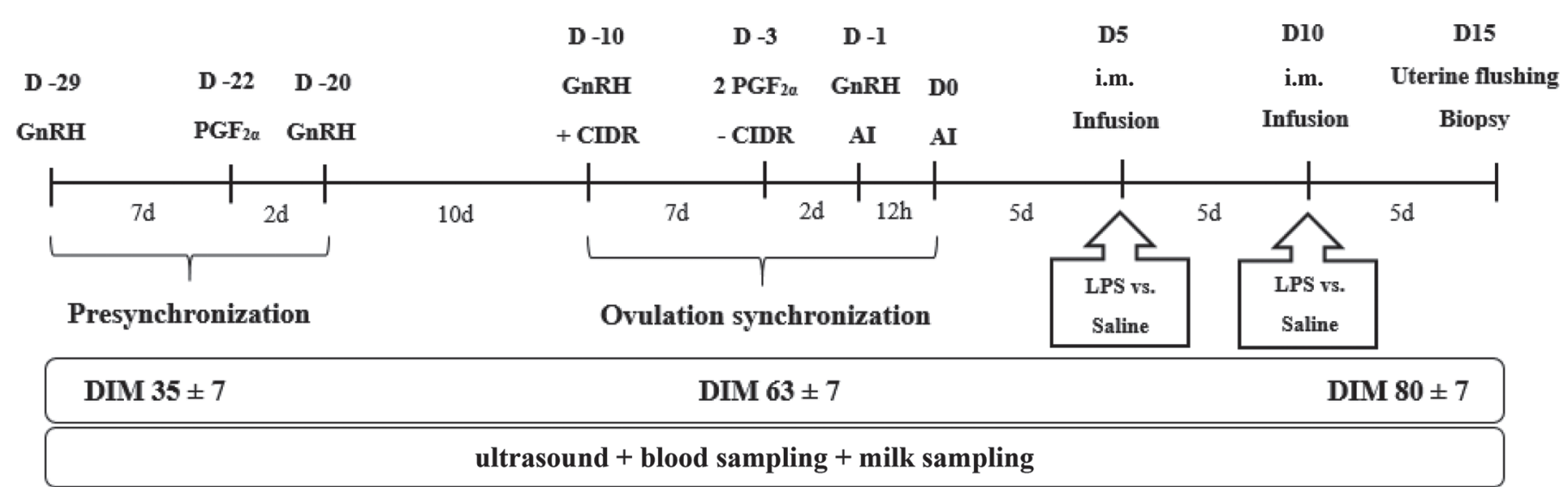

Figure 1. Diagram of the study. Presynchronization protocol between $\mathrm{d}-29$ and 20 and ovulation synchronization between $\mathrm{d}-10$ and 0 , with $2 \mathrm{PGF}_{2 \alpha}$ injections on $\mathrm{d}-3$ and $2 \mathrm{AI}$, the first one immediately after the last $\mathrm{GnRH}$ injection $(\mathrm{d}-1)$ and the second $\pm 12 \mathrm{~h}$ after the first AI. The ovaries of the cows were scanned by ultrasound to evaluate the response to the hormonal treatment. Intramammary infusions were performed on d 5 and 10 relative to the last AI, whereas uterine flushing and endometrial biopsies were performed on d 15 . Blood and milk samples were taken at different times during the trial. CIDR $=$ controlled internal drug release. 
SCC analysis. The samples were collected after milking routine procedures (predipping and teat drying with paper towel). Samples were then shipped on the same day to a private laboratory for subsequent culture and analyses (CanWest DHI, Chilliwack, BC, Canada). The milk samples for SCC were collected in vials containing 2-bromo-2-nitropropane-1-3-diol and analyzed by flow cytometry (Somacount 300; Bentley Instruments Inc., Chaska, MN). Milk samples (100 $\mu \mathrm{L})$ were plated on agar medium supplemented with defibrinated sheep blood $(10 \%)$ and in MacConkey agar medium. The samples were incubated aerobically at $37^{\circ} \mathrm{C}$ for 24 to $48 \mathrm{~h}$. The colonies were subjected to biochemical and bacterial differentiation tests. The description of the colony morphology of the plates was conducted 24 and $48 \mathrm{~h}$ after plating. The micromorphology was carried out using the slide smear method and stained by the Gram technique. The microbiological identification was based on morphological, biochemical, and staining characteristics. Daily milk yield was recorded during the experiment via inline sensors on a per-milking basis for further analysis.

\section{Blood Sampling for Haptoglobin, TNF-a, and Progesterone Analysis}

Blood samples were collected immediately before every hormonal treatment during synchronization protocols and at timed AI (d -29, -22, -20, -10, -3, -1 , and 0 ). Samples were also taken at days before infusions (d 4 and 9), at infusions days (d 5 and 10), 1 $\mathrm{d}$ after treatments (d 6 and 11), $1 \mathrm{~d}$ before endometrial biopsy (d 14), and at endometrial biopsy (d 15). Blood samples were harvested by puncture of the median coccygeal vein or artery using heparinized and nonheparinized Vacutainer tubes (Becton Dickinson, Franklin Lakes, NJ). Tubes were placed on ice immediately after collection, transported to the laboratory, and centrifuged at $2,000 \times g$ for $15 \mathrm{~min}$ at $4^{\circ} \mathrm{C}$. Plasma and serum were stored at $-80^{\circ} \mathrm{C}$ until subsequent analysis.

Haptoglobin concentrations were analyzed based on a methodology described by Makimura and Suzuki (1982), which quantifies the formation of hemoglobinhaptoglobin complex by estimating the difference of peroxidase activity in serum and read at a $450-\mathrm{nm}$ wavelength. Commercial ELISA kits were used to determine plasma concentrations of TNF- $\alpha$ (RayBio bovine TNF- $\alpha$ ELISA kit; RayBiotech Inc., Norcross, GA) and progesterone (Ovucheck Plasma; Biovet, Saint-Hyacinthe, QC, Canada). The haptoglobin assay had intra- and interassay coefficients of variation of 5.8 and $7.8 \%$ (7 runs), respectively, with a sensitivity of
0.10 optical density (OD). The intra- and interassay coefficients of variation of the progesterone assay were 5.3 and $6.9 \%$ (8 runs), respectively, with a sensitivity of $0.24 \mathrm{ng} / \mathrm{mL}$. The minimum detectable concentration was $0.1 \mathrm{ng} / \mathrm{mL}$. A microplate reader (Gemini EM fluorescence microplate reader; Molecular Devices, San Jose, CA) was used to evaluate all the colorimetric reactions.

\section{Rumen-Reticular Temperature}

Body temperature was monitored during the entire experimental period. In the first week postpartum, cows received a temperature-sensing rumen-reticular bolus (TempTrack; DVM Systems, Greeley, CO) administered orally using the appropriate gun. The bolus is a cylinder measuring $95 \mathrm{~mm} \times 23 \mathrm{~mm}$, and it rests inside the reticulum of the cows. Some stationary panel readers were installed in the freestall and 1 was installed at the exit of the milking parlor, which served to power the bolus and obtain a rumen-reticular temperature (RT) reading every time a cow passed the reader. These readings were sent to the farm computer for further analysis.

The electronic system used to measure RT in this study replaced the conventional method of rectal temperature measurement with a digital thermometer. According to Bewley et al. (2008), a significant correlation exists between $\mathrm{RT}$ and rectal temperatures (r $=0.645)$, and $\mathrm{RT}$ is $0.45 \pm 0.33^{\circ} \mathrm{C}$ higher than rectal temperature.

\section{Conceptus Collection and Endometrial Biopsy}

On d 15 post-AI (d 15), uterine flushing for embryo recovery was performed, and $1 \mathrm{~d}$ prior (d 14) the ovaries of the cows were scanned to check for the presence of a CL and its side. Cows received an epidural anesthesia with $2 \mathrm{~mL}$ of lidocaine hydrochloride $2 \%$ (Bimeda Animal Health Inc., Cambridge, ON, Canada), and the external genitalia were cleaned using water, paper towels, and $70 \%$ alcohol. For collection, a Foley catheter was inserted into the vagina through the cervix and then into the uterus in the direction of the ipsilateral horn to the CL. Using an empty syringe, the catheter balloon was inflated with air to avoid reflux of the injected solution. In one arm of the Y-tube a commercial flush solution bag (Bioniche Life Sciences Inc., Belleville, ON, Canada) was attached to flush the horn. The embryo collection filter was attached in the second arm of the Y-tube and held below cow level; thus, the solution flowed to the filter by gravity. At the end of 
flushing (about $300 \mathrm{~mL}$ of flushing solution), filters were capped, placed on ice, transported to the laboratory, and washed with $0.85 \%$ sodium chloride, and their content was transferred to a Petri dish. Embryos were measured inside the Petri dish using a ruler. The ovoid embryos were measured using a stereomicroscope (SMZ-745T; Nikon, Tokyo, Japan).

After the uterine flushing procedure, endometrial biopsies were performed. The endometrial biopsy forceps $(3.5-\mathrm{mm} \times 8-\mathrm{mm}$ bite and 50.8-cm shaft; KevorkianYounge, Fine Surgicals, Aries Surgical, Davis, CA) covered with a plastic sheath were inserted into the vagina through the cervix and into the uterus in the direction of the ipsilateral horn to the CL. Inside the uterus, the first endometrial tissue sample was collected from the caudal portion of the ipsilateral uterine horn. The forceps were removed from the cow with the sample in the clamp, and the tissue fragment was collected using tweezers. The same procedure was repeated to collect the second endometrium tissue sample from the cranial portion of the same uterine horn. Approximately 100 to $200 \mathrm{mg}$ of endometrial tissue was collected from each cow. The 2 endometrial samples of each cow were placed in the same cryovial with RNAlater (Qiagen Inc., Toronto, Canada). The tubes were frozen in a $-80^{\circ} \mathrm{C}$ freezer.

\section{RNA Extraction}

Total RNA from endometrium samples from pregnant uteri was extracted using a TRIzol Plus RNA purification kit (Invitrogen, Carlsbad, CA) according to the manufacturer's recommendations. The tissue: trizol ratio (mg:mL) was 100:1 for all samples (1-mL of TRIzol per 50 to $100 \mathrm{mg}$ of tissue). Quantity and quality of extracted RNA were estimated using a NanoDrop spectrophotometer (ND-2000, NanoDrop Technologies Inc., Wilmington, DE) at $260 \mathrm{~nm}$ absorbance wave and 260:280-nm absorbance ratio, respectively. Total RNA extracted was stored at $-80^{\circ} \mathrm{C}$ until further processing.

\section{Gene Expression Analysis}

For gene expression tests, only endometrial samples from pregnant cows were considered in the analysis (control $=5$; LPS $=6$ ). Endometrial mRNA expression was assessed by a validated (Kim et al., 2018) single-molecule imaging of targeted mRNA molecules hybridized with color-coded probe pairs and molecular barcodes using the NanoString nCounter System (NanoString Technologies, Seattle, WA), which were custom designed for 96 target and 4 reference genes
(Table 1). The target mRNA was mixed in solution with a large excess of the reporter and capture probe pairs so that each targeted transcript found its corresponding probe pair. After hybridization, excess unbound probes were washed away and the tripartite complexes, comprising target mRNA bound to specific reporter-capture probe pairs, were isolated. The biotin label at the $3^{\prime}$ end of the capture probes was used to attach the complexes to streptavidin-coated slides. An electric field was applied to orient and extend the tripartite complexes on the surface of the slide to facilitate imaging and detection of the color-coded molecules. A microscope objective and a charge-coupled device camera were then used to image the immobilized complexes using 4 different excitation wavelengths $(480,545,580$, and $622 \mathrm{~nm}$ ) corresponding to the 4 fluorescent dyes. The different combinations of the 4 distinct colors allow for a large diversity of color-based barcodes, each designating a different gene transcript. The expression level of a gene was measured by counting the number of times the specific barcode is detected, and the barcode counts were tabulated in a comma-separated value format.

\section{Statistical Analysis}

All statistical analyses were conducted using SAS version 9.4 (SAS Institute Inc., Cary, NC). In all models, cows were used as the experimental unit. Normality was visually tested in all continuous variables using the UNIVARIATE procedure of SAS and tested for homogeneity of variance by the Kolmogorov-Smirnov procedure. The mRNA expression data of 47 transcripts were log-transformed. Similarly, embryo length measurements were also log-transformed. The variable SCC is described herein as the $\log _{10}$-transformed value of the SCC (cells $/ \mathrm{mL}$ of milk). Similarly, the variable haptoglobin is described as the ln-transformed value of the raw haptoglobin values (OD).

Continuous data without repeated measurements (i.e., DIM, parity, BCS, milk yield and SCC at enrollment, progesterone concentration in plasma according to pregnancy status, and CL diameter and embryo length at d 15 of gestation) were analyzed by ANOVA using the MIXED procedure of SAS, and treatment was included in the model as the fixed effect. For progesterone concentration according to pregnancy status, treatment, pregnancy status, and the interaction between treatment and pregnancy status were included as fixed effects. The MIXED procedure of SAS was used to analyze continuous data with repeated measurements (i.e., milk yield, SCC, haptoglobin, TNF- $\alpha$, RT, and BCS). 
For analyses of repeated measurements, the repeated statement was used and treatment, infusion (first vs. second), day, hour, and the interactions between treatment and infusion, day, and hour after infusions were included in the model as fixed effects. The structure of covariance (autoregressive, unstructured, or compound symmetry) was chosen according to the Bayesian information criteria. Treatment was included as the random effect, and cows were nested within treatment.

An ANOVA was used to analyze the effects of treatment on endometrium gene expression using the MIXED procedure of SAS with treatment as a fixed effect. A Tukey-Kramer adjustment test was performed to correct for familywise (multiple) comparison. Statistical significance of the contrast analysis was defined as $P \leq 0.05$, and a tendency was defined as $0.05<P$ $\leq 0.10$.

\section{RESULTS}

\section{Descriptive Parameters}

Four cows $($ control $=1 ; \mathrm{LPS}=3$ ) were removed from the experiment. One cow did not fully respond to the synchronization protocol (failure to ovulate to final GnRH injection), and in 3 cows there were difficulties performing the uterine flushing and biopsies.

At enrollment, average DIM (control $=32.5 \pm 1.6$, LPS $=35.7 \pm 1.8 ; P=0.21$ ), lactation number (control $=2.4 \pm 0.5$, LPS $=2.3 \pm 0.6 ; P=0.97)$, and BCS (control $=2.91 \pm 0.05$, LPS $=2.89 \pm 0.05 ; P=$ 0.83 ) were similar between treatments. After ovulation synchronization and timed AI but before onset of treatments, milk yield from d -29 to 4 (control $=34.0 \pm$ $2.9, \mathrm{LPS}=36.6 \pm 2.9 \mathrm{~kg} / \mathrm{d} ; P=0.53)$ and $\mathrm{SCC}$ on $\mathrm{d} 0$ $($ control $=1.5 \pm 0.2, \mathrm{LPS}=1.9 \pm 0.2$ cells $/ \mathrm{mL}$ of milk; $P=0.20)$ were similar between treatments. All cows had negative bacterial growth on milk cultures.

\section{Milk Yield and SCC After Treatment}

All cows treated with LPS displayed acute mastitis signals, such as udder edema in the infused teat and presence of milk clots at subsequent milkings. The LPS cows had lower milk yield after treatment from d 5 to $15($ control $=34.3 \pm 1.5$, LPS $=29.4 \pm 1.5 \mathrm{~kg} / \mathrm{d} ; P=$ $0.01)$ than the control cows. Milk yield was also influenced by day $(P=0.05)$, but an interaction between treatment and day $(P=0.28)$ was not verified (Figure 2).

The LPS infusions stimulated the migration of a large amount of leucocytes to the challenged quarter, which was responsible for an increase of SCC from the rear left teat. The SCC started to increase during the first hours after each challenge, persisted high from 10 to 34 $\mathrm{h}$ after treatment, and returned to normal levels until $96 \mathrm{~h}$ after each challenge. The mean SCC was altered by treatment (control $=2.3 \pm 0.1$, LPS $=3.3 \pm 0.1$ $\log _{10}$ SCC; $\left.P<0.01\right)$, hours relative to infusion $(P<$ $0.01)$, and interactions between treatment and infusion $(P<0.01$; Figure $3 \mathrm{~A}$ and $\mathrm{B})$.

\section{Inflammatory Parameters}

Serum concentration of haptoglobin was altered by treatment $($ control $=0.25 \pm 0.07$, LPS $=0.89 \pm 0.07$ $\log _{10}$ OD; $\left.P<0.01\right)$. Haptoglobin was similar between treatments up to d 5 postinfusion and then was significantly greater in LPS cows from d 6 to 14 postinfusion $(P<0.01 ;$ Figure 4$)$.

The intramammary challenge with LPS did not induce $T N F-\alpha$ production by host defense cells once this cytokine plasma concentration was not affected by treatment (control $=0.6 \pm 0.1, \mathrm{LPS}=0.5 \pm 0.1 \mathrm{ng} /$ $\mathrm{mL} ; P=0.19)$ or by day $(P=0.40)$. There was no interaction between treatment and day on $\mathrm{TNF}-\alpha$ plasma concentration $(P=0.55$; Figure 5$)$.

Rumen-reticular temperature from LPS cows became significantly greater at $5 \mathrm{~h}$ after each infusion and remained high until $10 \mathrm{~h}$ after infusion, reaching a peak of $40.9^{\circ} \mathrm{C}$ at $8 \mathrm{~h}$ after the first challenge. The RT was altered by treatment $($ control $=39.5 \pm 0.1, \mathrm{LPS}=40.1$ $\left.\pm 0.1^{\circ} \mathrm{C} ; P<0.01\right)$ and by time relative to infusion $(P$ $<0.01$ ). Interaction between treatment and time was verified $(P<0.01$; Figure 6$)$.

\section{Reproductive Parameters}

Mean concentration of progesterone in plasma during the entire experimental period was not different between treatments (control $=3.6 \pm 0.3$, LPS $=3.1 \pm$ $0.4 \mathrm{ng} / \mathrm{mL} ; P=0.37)$. From the beginning of presynchronization until the end of the ovulation synchronization protocol ( $d-29$ to -1$)$, all cows responded to the hormonal treatments, and concentration of progesterone in plasma had a similar pattern during the synchronization of ovulation program in both treatments (control $=4.0 \pm 0.4, \mathrm{LPS}=3.2 \pm 0.5 \mathrm{ng} / \mathrm{mL} ; P=$ $0.20)$, with differences among days during synchronization protocols $(P<0.01)$. Progesterone concentration in plasma after ovulation from d 0 to 15 was not affected by treatment (control $=3.3 \pm 0.4$, LPS $=3.1$ $\pm 0.4 \mathrm{ng} / \mathrm{mL} ; P=0.69)$. There was an effect of day 
Table 1. Genes and accession numbers according to National Center for Biotechnology Information (Bethesda, MD)

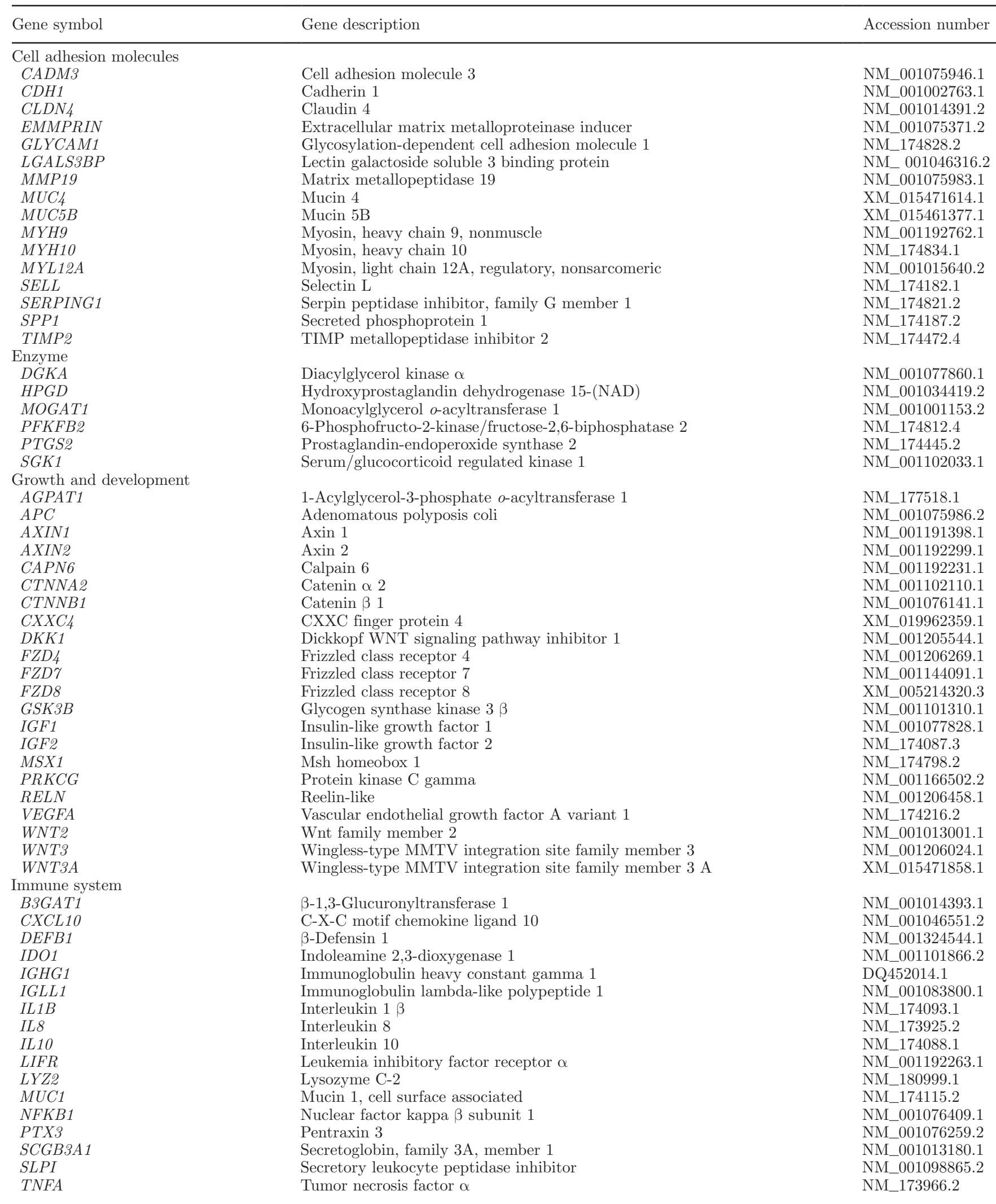


Table 1 (Continued). Genes and accession numbers according to National Center for Biotechnology Information (Bethesda, MD)

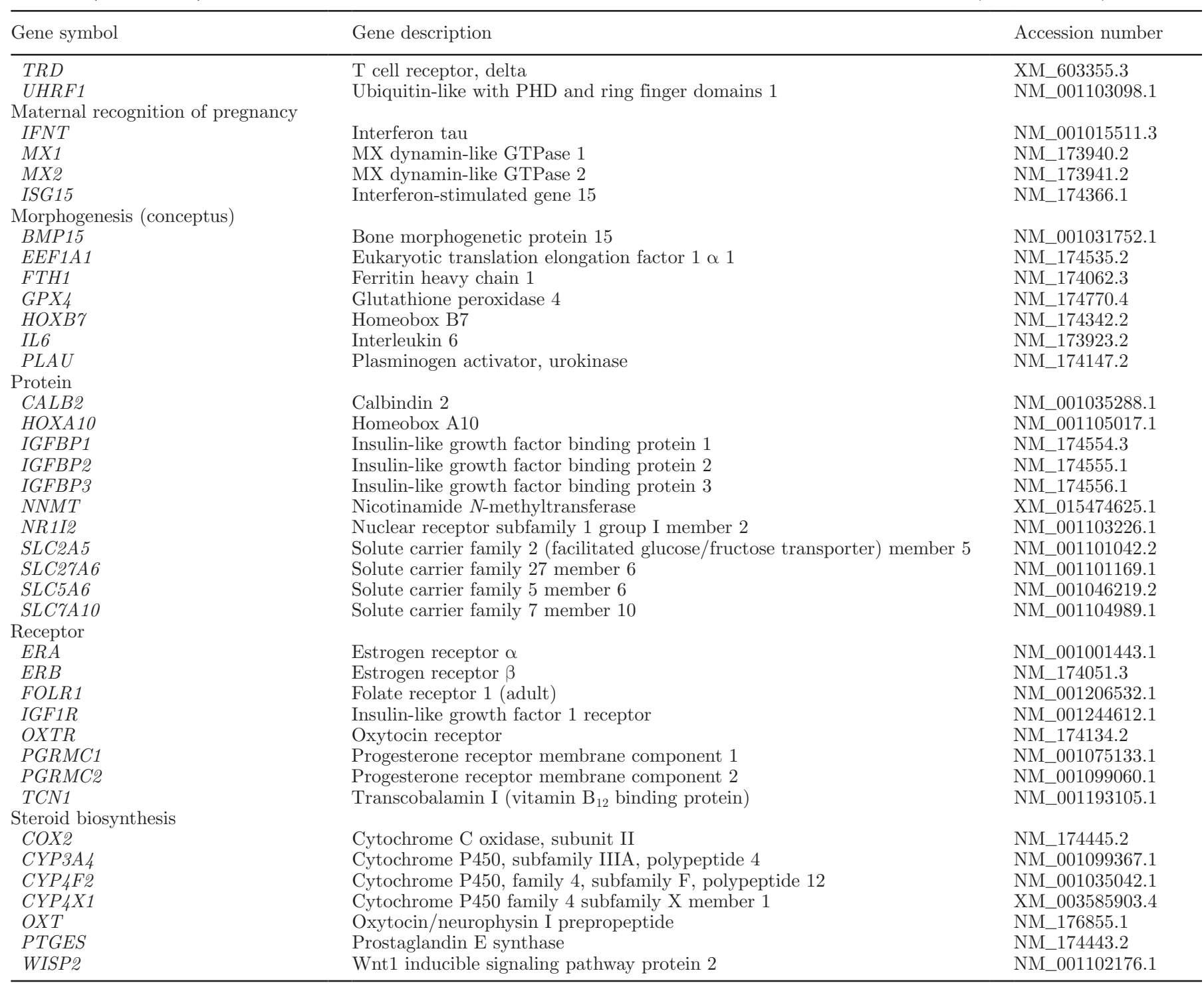

$(P<0.01)$, but an interaction between treatment and day $(P=0.77)$ on progesterone concentrations was not observed (Figure 7). Regardless of treatment influence, progesterone concentrations from d 0 to 15 did not differ between pregnant and nonpregnant cows on d 15 (pregnant $=3.2 \pm 0.4$, open $=3.1 \pm 0.4 \mathrm{ng} / \mathrm{mL} ; P=$ 0.81 ), and there was no interaction between treatment and pregnancy $(P=0.78)$.

Overall embryo recovery was $55 \%(11 / 20)$, and was $66.7 \%(6 / 9)$ for the LPS group and $45.5 \%(5 / 11)$ for the control group. There was no effect of treatment on CL diameter $($ control $=27.5 \pm 0.9, \mathrm{LPS}=25.5 \pm 1.0$ $\mathrm{mm} ; P=0.17$ ) and embryo length on $\mathrm{d} 15$ of gestation $($ control $=6.37 \pm 2.08$, LPS $=2.47 \pm 1.47 \mathrm{~cm} ; P=$ $0.17)$.

\section{Gene Expression}

From the 96 target genes analyzed (Table 1), endometrial expression of 13 genes was significantly modulated $(P<0.05)$ by mammary LPS challenge. A tendency of treatment effect $(0.05 \geq P<0.10)$ was observed in 17 genes (Table 2). From the cell adhesion category, the levels of CADM3, EMMPRIN, MMP19, and SERPING1 transcripts were upregulated, with 1.9-, 1.2-, 1.5-, and 1.3-fold increases, respectively, in LPS-challenged cows. The IGF2 and AXIN1, both transcripts that belong to the growth and development group, were also different between LPS and control cows, with a 1.4- and 1.2-fold difference, respectively. For the PTX3 gene, from the immune system group, we observed a 2.3 -fold 


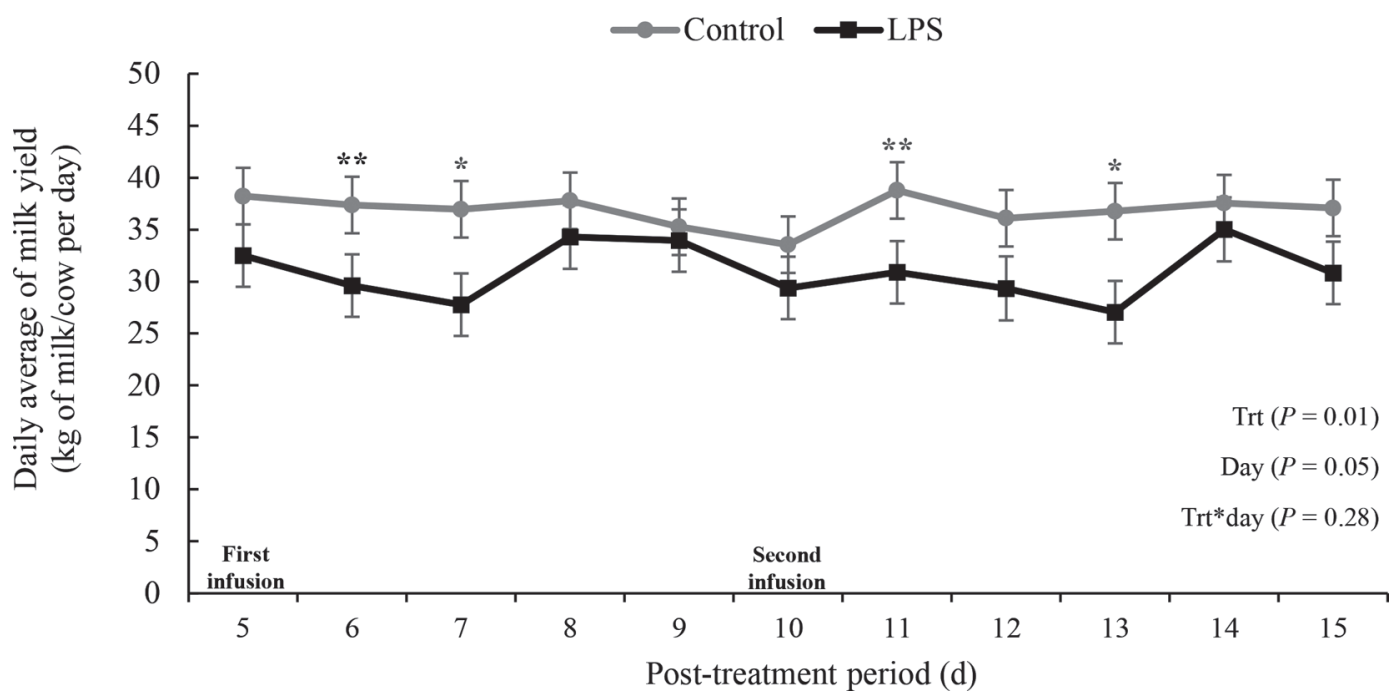

Figure 2. Daily average milk yield according to treatment (Trt) and day relative to each intramammary infusion. Control $=$ cows were infused twice with saline on d 5 and 10 relative to AI; LPS $=$ cows were infused twice with $25 \mu \mathrm{g}$ of LPS on d 5 and 10 relative to AI. Results are reported as LSM \pm SEM. ${ }^{*} P<0.01 ;{ }^{* *} P<0.05$.

increase in endometrium collected from LPS cows. The SLC27A6 gene that encodes a member of the fatty acid transport protein family was 0.35 -fold less expressed in LPS cows than in control cows. Endometrial gene transcription analysis showed that the mRNA levels of genes related to enzyme ( $S G K ; 3.5$-fold increase), receptor (TCN1; 2.5-fold increase) and steroid (CYP3A4; 1.7-fold increase) biosynthesis differed significantly between control and LPS cows $(P<0.05)$. Moreover, transcript levels of 2 genes related to morphogenesis (FTH1 and GPX4) were affected by treatment $(P \leq$ $0.05)$, with a same fold increase of 1.2 for both. In relation to maternal recognition of a pregnancy-related gene, IGS15 expression in the endometrium tended to be 4.3 -fold increased by LPS $(P=0.10)$. The complete list of modulated target transcripts in the endometrium is shown in Table 2.

\section{DISCUSSION}

The mastitis-induced protocol using gram-negative endotoxin was able to trigger an inflammatory response after each LPS infusion, causing temporary hyperthermia, increased SCC, decreased milk production, and increased serum haptoglobin. The sequence of 2 LPS intramammary infusions did not compromise CL diameter or concentrations of progesterone before and after AI. Likewise, the recovery rate and conceptus length were similar between the 2 treatments, although the conceptus from LPS-treated cows was less than half the mean length of the conceptus from control cows. On the contrary, the endometrium gene expression was significantly modulated by the LPS treatments in 13 target genes in the endometrium at d 15 of gestation, and 17 presented a tendency with various magnitudes of fold change; this presents important information on the interference of LPS in endometrium receptivity and early embryo development. Particular attention was given to the endometrium's cell adhesion ( $C A D M 3$, EMMPRIN, SELL, SERPING1), immune system (PTX3, IL6, TCN1), Wnt signaling pathway (FZD4, FZD\%, WNT2), and interferon-stimulated (ISG15, $M X 2, B M P 15)$ genes.

In the current study, hyperthermia started around $5 \mathrm{~h}$ and lasted until $10 \mathrm{~h}$ after each infusion in LPSchallenged cows (Figure 6A and 6B), similar to the pattern reported by Jackson et al. (1990). Other authors verified a rectal temperature increase in cows after intramammary infusion of LPS (Jacobsen et al., 2004; Zimov et al., 2011). Nevertheless, this increase in cows' body temperature may also impair early embryonic development of lactating dairy cows (Hansen and Arechiga, 1999). As a consequence of hyperthermia, some changes may have occurred in LPS-treated cows, particularly the reduction in DMI and energy expenditure for thermoregulation and activation of an immune response. Although DMI was not evaluated in our study, we believe that the previously mentioned factors probably contributed to the lower milk yield found in the LPS group. In contrast, Zimov et al. (2011) reported a reduction in milk yield following the $2 \mathrm{~d}$ after LPS challenge without a decrease in DMI. According to the authors, this could be related to an injury at the mammary gland epithelium associated 

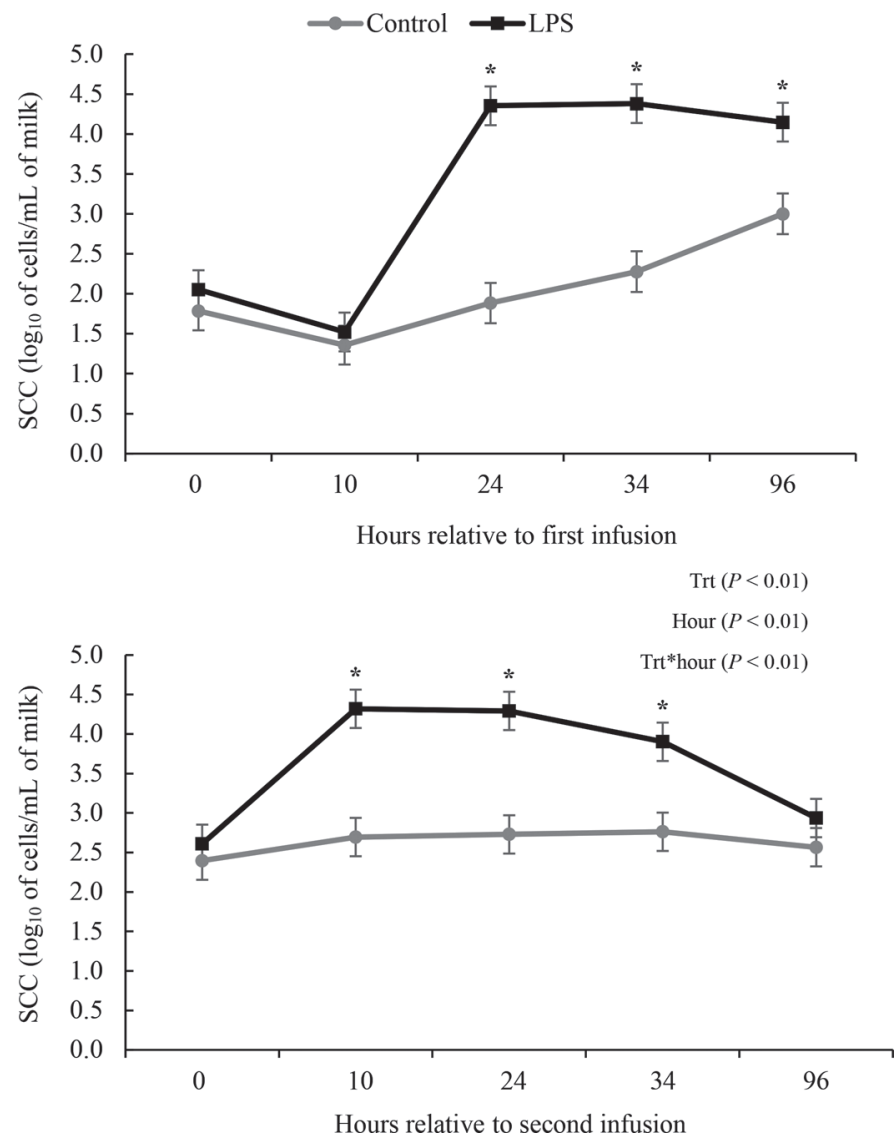

Figure 3. Somatic cell counts according to treatment (Trt) and day relative to each intramammary infusion (top: first infusion; bottom: second infusion). Control $=$ cows were infused twice with saline on d 5 and 10 relative to AI; LPS $=$ cows were infused twice with 25 $\mu \mathrm{g}$ of LPS on d 5 and 10 relative to AI. Results are reported as LSM \pm SEM. ${ }^{*} P<0.01$.

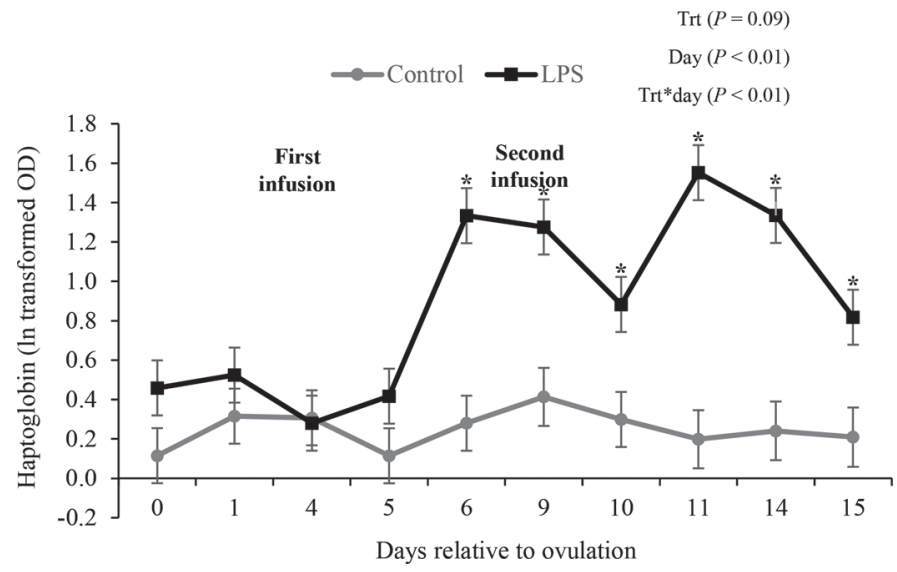

Figure 4. Haptoglobin serum concentration [optical density (OD) at $450 \mathrm{~nm}$ ] according to treatment (Trt) and day relative to each intramammary infusion. Control $=$ cows were infused twice with saline on d 5 and 10 relative to AI; LPS $=$ cows were infused twice with 25 $\mu \mathrm{g}$ of LPS on d 5 and 10 relative to AI. Results are reported as LSM \pm SEM. ${ }^{*} P<0.01$ with higher permeability and escape of substrate required for milk synthesis. The SCC elevation observed at the subsequent milking after LPS infusion $( \pm 10 \mathrm{~h})$ denotes that the immune system of the dairy cow is efficient to rapidly recognize and respond to the endotoxin by significantly recruiting leucocytes to the mammary gland. This response was expected and used in this study as a major marker of mammary gland inflammatory response. A faster recruitment of leukocytes to the mammary gland translates into a more effective capture and elimination of the endotoxin from the host organism (Burvenich et al., 2007). In the current experiment, $\mathrm{TNF}-\alpha$ concentrations were similar between treatments; therefore, the bacterial endotoxin may not have been able to promote this specific cytokine production and release. Because the cytokines can be synthetized by a variety of cellular types whether or not they belong to the immune system, it is possible that LPS might have stimulated the production of cytokines other than TNF- $\alpha$. Despite that, the LPStreated cows presented a greater serum haptoglobin concentration in plasma, which acts as a nonspecific inflammatory marker. Dairy cows with clinical mastitis had greater concentrations of haptoglobin in blood and milk compared with healthy cows (Eckersall et al., 2001; Nielsen et al., 2004), and results from the current experiment corroborated this finding. Collectively, there is enough evidence to prove that a significant local and systemic inflammatory response was caused by the intramammary infusion of LPS. However, it is noteworthy that the lack of plasma TNF- $\alpha$ increase in LPS-treated cows could indicate that the changes observed in the endometrium actually originated from indirect LPS changes not necessarily associated with the immune response.

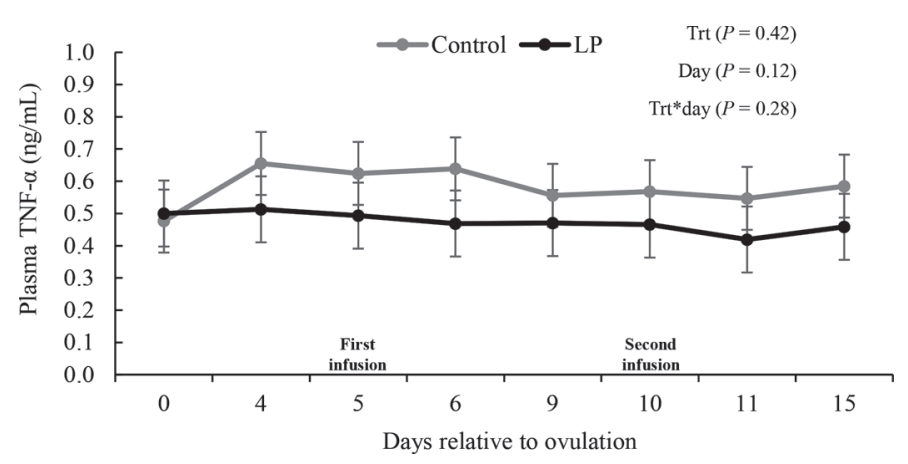

Figure 5. Tumor necrosis factor (TNF)- $\alpha$ plasma concentration according to treatment (Trt) and day relative to each intramammary infusion. Control $=$ cows were infused twice with saline on d 5 and 10 relative to AI; LPS = cows were infused twice with $25 \mu \mathrm{g}$ of LPS on d 5 and 10 relative to AI. Results are reported as LSM \pm SEM. 
The LPS challenge was not able to induce lower progesterone concentrations between treatments, which contradicted our initial hypothesis but proved that changes found in the endometrium were not confounded by ovarian steroid concentrations. Giri et al. (1990) reported an increase in $\mathrm{PGF}_{2 \alpha}$ synthesis after an LPS challenge that caused reduction in progesterone concentration regardless of dosage and pregnancy stage in cows. Ribeiro et al. (2016) found a lower concentration of progesterone in plasma from cows affected by both uterine and nonuterine diseases. In the current experiment, regardless of treatment, progesterone concentrations in plasma were similar between pregnant and nonpregnant cows in accordance with the results found by Ribeiro et al. (2016).

The LPS-induced inflammatory response did not affect conceptus length and recovery at d 15 of gestation. Despite the lack of statistical significance, the length of the conceptuses from LPS-treated cows was on average half the length of those from control cows. The work from Ribeiro et al. (2016) found no effect of uterine and nonuterine disease occurrence on proportion of pregnant cows at $15 \mathrm{~d}$ post-AI, but they found shorter conceptuses that produced less IFNT. The gene expression profile between long and short conceptuses of the same age showed differences in 348 genes, which could

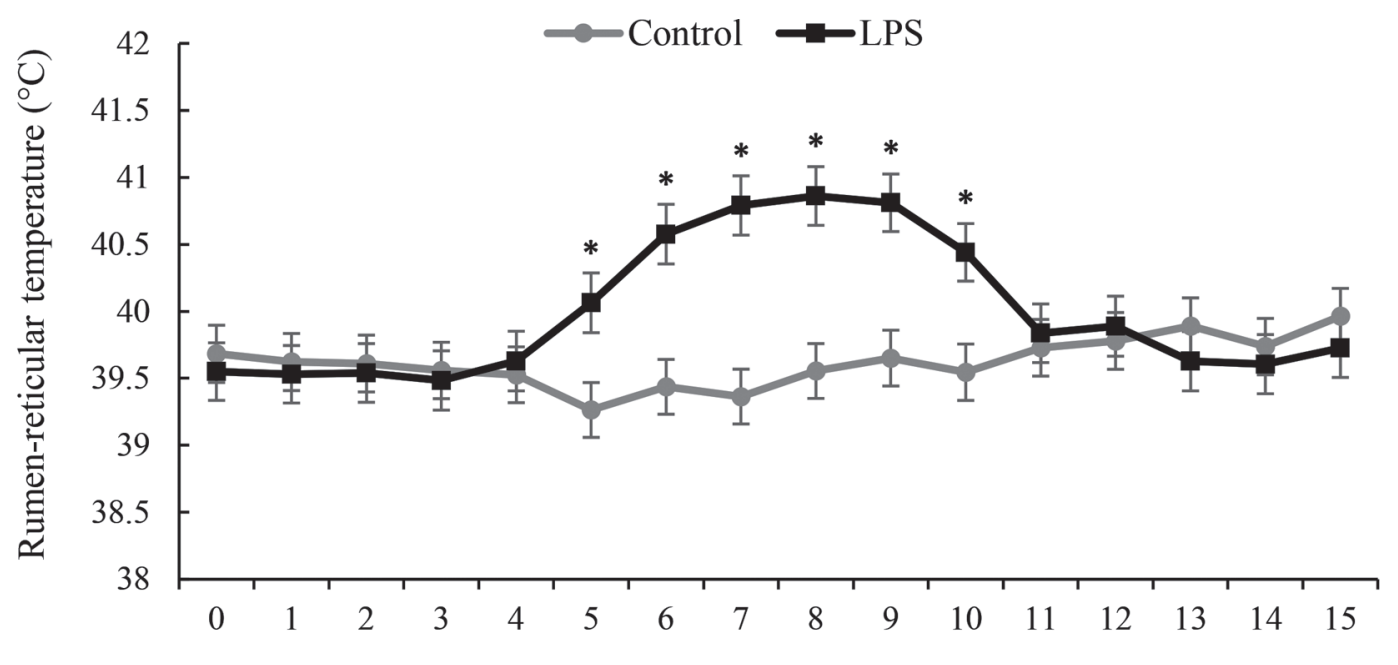

Hours relative to first infusion

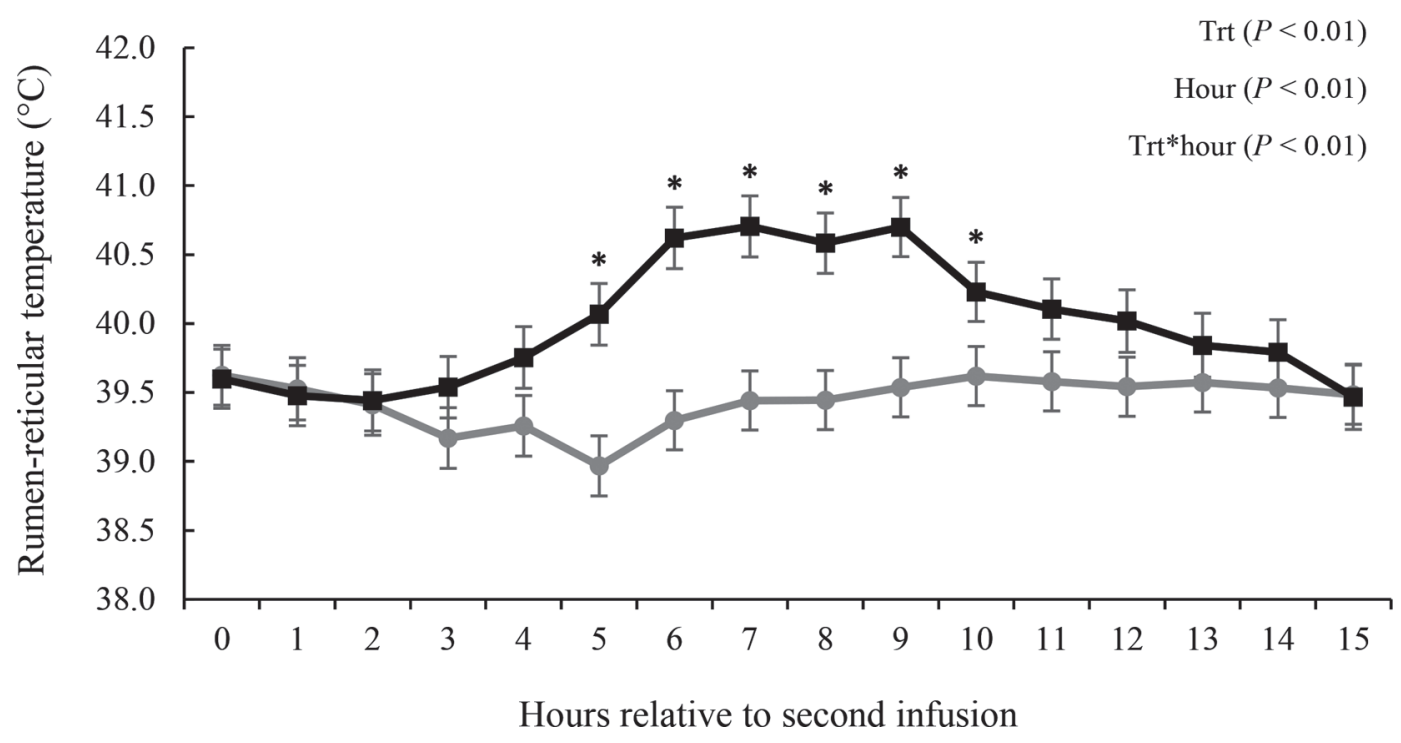

Figure 6. Rumen-reticular temperature according to treatment (Trt) and hour relative to each intramammary infusion (top: first infusion; bottom: second infusion). Control = cows were infused twice with saline on d 5 and 10 relative to AI; LPS $=$ cows were infused twice with 25 $\mu \mathrm{g}$ of LPS on d 5 and 10 relative to AI. Results are reported as LSM \pm SEM. ${ }^{*} P<0.01$. 


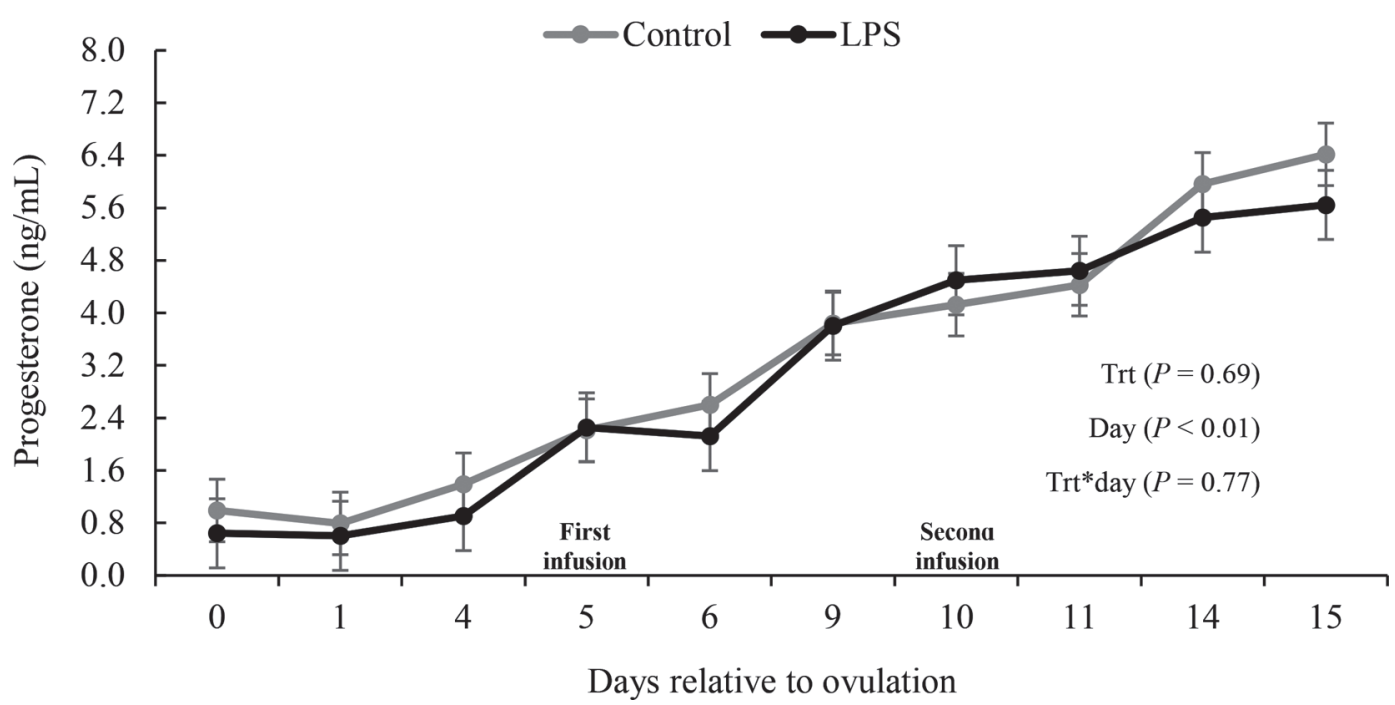

Figure 7. Progesterone plasma concentration according to treatment (Trt) and day relative to each intramammary infusion. Control $=$ cows were infused twice with saline on d 5 and 10 relative to AI; LPS $=$ cows were infused twice with $25 \mu \mathrm{g}$ of LPS on d 5 and 10 relative to AI. Results are reported as LSM \pm SEM.

be explained by a lack of development competence or an asynchrony between embryo and maternal uterine environment (Barnwell et al., 2016).

The IFNT conceptus gene expression seems to occur due to genetic programming regardless of uterine environment influence, and its expression ends with conceptus implantation around d 19 of gestation (Demmers et al., 2001; Forde et al., 2011). Three important interferon-stimulated genes (ISG15, MX2, and $B M P 15)$ were modulated in the endometrium by LPS intramammary infusions. This finding implies that, despite similar circulating progesterone, the non-uterineinduced inflammation indeed communicated with the endometrium, likely decreasing its capacity to sustain early embryonic development. Two of these interferonstimulated genes are ISG15 and MX2, whose expression increases in the endometrium of pregnant ruminants (Austin et al., 1996). Forde et al. (2011) reported an 8 -fold increase in $I S G 15$ expression in the endometrium of pregnant heifers. In our study, ISG15 and MX2 expression in endometrial tissue tended to be greater in LPS cows, which had a greater than 2-fold change in relation to control cows. Sometimes the modulation of genes in the endometrium can be misleading regarding the direction (up- or downregulation) of where the gene is expressed. We believe that this overexpression of $I S G 15$ and $M X 2$, which could be initially interpreted as a positive effect of LPS, must be a compensatory mechanism induced by the endometrium to protect and improve cross-communication between conceptus and endometrium. However, the mechanisms are unclear at this point and should be further investigated.
The upregulation of cell adhesion-related genes (EMMPRIN and MMP19) involved in endometrial tissue remodeling during the preimplantation period and then in the regulation of conceptus attachment in the bovine endometrium is in accordance with previous studies (Bauersachs et al., 2008; Mishra et al., 2012). Other genes involved in cell adhesion found in this study, such as those belonging to the cadherin family and SELL, have also been reported elsewhere (Bauersachs et al., 2008; Cerri et al., 2012). The involvement of adhesion-related genes in the regulation of the preimplantation endometrium is well established. The timing, however, is something that deserves further investigation, particularly when studying the effects of systemic stressors on the reproductive tract. Different reports collecting endometrium samples from d 14 to 19 indeed show some wide variation in the expression and direction of expression of these transcripts (Bauersachs et al., 2008; Forde et al., 2011; Cerri et al., 2012).

The SERPING1 and PTX3 genes play an important role in embryo-maternal immune modulation. Generally, the 2 transcripts have immunosuppressive and antiproliferative properties that prevent rejection of the conceptus by the maternal complement system (Klein et al., 2006; Ulbrich et al., 2009; Walker et al., 2010). Serpins proteins are secreted by the glandular epithelium during bovine pregnancy and regulated by progesterone and estrus (Ulbrich et al., 2009). In agreement with our findings, Klein et al. (2006) verified an upregulation of SERPING1 until $18 \mathrm{~d}$ of gestation in cows with similar progesterone concentrations. The PTX3 upregulation in pregnant cows prevents comple- 
Table 2. Effect of treatment of lactating dairy cows with intramammary infusions of lipopolysaccharide on endometrium gene expression (mean $\pm \mathrm{SEM}$ ) on d 15 of pregnancy according to major functions

\begin{tabular}{|c|c|c|c|c|}
\hline \multirow[b]{2}{*}{ Gene } & \multicolumn{2}{|c|}{ Treatment $^{1}$} & \multirow[b]{2}{*}{$P$-value ${ }^{2}$} & \multirow[b]{2}{*}{ Fold change } \\
\hline & Control & LPS & & \\
\hline$C A D M 3$ & $273.99 \pm 1.17$ & $526.93 \pm 1.15$ & 0.01 & 1.93 \\
\hline$E M M P R I N$ & $2,070.95 \pm 101.88$ & $2,480.06 \pm 93.00$ & 0.02 & 1.20 \\
\hline MMP19 & $621.90 \pm 1.12$ & $926.15 \pm 1.10$ & 0.02 & 1.49 \\
\hline MYH9 & $4,638.64 \pm 359.98$ & $5,461.32 \pm 328.61$ & 0.10 & 1.18 \\
\hline \multicolumn{5}{|c|}{ Growth/development/morphogenesis } \\
\hline AGPAT & $1,132.76 \pm 1.08$ & $1,415.43 \pm 1.08$ & 0.07 & 1.25 \\
\hline AXIN1 & $508.36 \pm 32.30$ & $625.40 \pm 29.48$ & 0.03 & 1.23 \\
\hline AXIN2 & $223.14 \pm 27.88$ & $290.69 \pm 25.45$ & 0.10 & 1.30 \\
\hline$F Z D 4$ & $429.99 \pm 64.15$ & $600.50 \pm 58.56$ & 0.08 & 1.40 \\
\hline$F Z D^{\prime} 7$ & $658.39 \pm 53.38$ & $779.35 \pm 48.73$ & 0.10 & 1.18 \\
\hline HOXA10 & $2,092.69 \pm 243.21$ & $2,710.67 \pm 222.02$ & 0.09 & 1.30 \\
\hline$N F K B$ & $940.93 \pm 65.01$ & $1,134.49 \pm 59.34$ & 0.06 & 1.21 \\
\hline РТX3 & $55.71 \pm 1.22$ & $130.08 \pm 1.20$ & 0.01 & 2.34 \\
\hline IL 6 & $1.32 \pm 1.57$ & $4.53 \pm 1.51$ & 0.08 & 3.42 \\
\hline СУРЗА 4 & $23.58 \pm 1.16$ & $39.05 \pm 1.15$ & 0.03 & 1.66 \\
\hline$G P X_{4}$ & $2,343.26 \pm 84.50$ & $2,700.08 \pm 77.14$ & 0.01 & 1.15 \\
\hline$P T G E S$ & $61.29 \pm 12.38$ & $91.90 \pm 11.30$ & 0.10 & 1.50 \\
\hline$S G K 1$ & $577.65 \pm 241.62$ & $2,049.63 \pm 220.57$ & $<0.001$ & 3.55 \\
\hline FTH1 & $4,869.41 \pm 412.31$ & $6,154.33 \pm 376.39$ & 0.05 & 1.26 \\
\hline SLC27A6 & $637.57 \pm 131.85$ & $221.70 \pm 120.36$ & 0.04 & 0.35 \\
\hline$S L C 7 A 10$ & $1.32 \pm 1.42$ & $3.55 \pm 1.37$ & 0.07 & 2.68 \\
\hline$T C N 1$ & $60.54 \pm 22.95$ & $153.11 \pm 20.95$ & 0.02 & 2.53 \\
\hline \multicolumn{5}{|c|}{ Interferon-stimulated genes } \\
\hline$B M P 15$ & $4.46 \pm 1.84$ & $1.23 \pm 1.35$ & 0.06 & 0.27 \\
\hline
\end{tabular}

${ }^{1}$ Control: $10 \mathrm{~mL}$ of saline $(\mathrm{n}=5)$; LPS: $25 \mu \mathrm{g}$ of lipopolysaccharide diluted in $10 \mathrm{~mL}$ of saline $(\mathrm{n}=6)$.

${ }^{2}$ Difference when $P \leq 0.05$ and tendency when $0.05<P \leq 0.10$.

${ }^{3}$ Fold change $=$ LPS in relation to control.

ment system cascade and excessive inflammatory reactions by inhibiting the classical complement pathway (Walker et al., 2010; Cerri et al., 2012). In the current study, the interpretation of the LPS upregulation of PTX3 was unclear because this transcript was highly upregulated. In a recent study by our group using 10-mo-old heifers challenged by LPS i.v., we observed a strong downregulation of PTX3 (A. C. C. Fernandes, S. Davoodi, M. Kaur, D. Veira, L. E. H. Melo, and R. L. A. Cerri, University of British Columbia, Vancouver, Canada, unpublished data), which clearly contradicts this finding. On the contrary, it is probably wise to limit direct comparisons between lactating cows and virgin heifers as they present vastly different scenarios regarding infectious and metabolic challenges. In the current study, we also observed a several-fold increase in the expression of $I L 6$, which could indicate a proinflammatory state induced by LPS, thus triggering an overexpression of $P T X 3$ in an attempt to compensate for the immune reaction imbalance. Another example of a potential compensatory effect in the endometrium triggered to possibly stabilize the endometrium is the upregulation of FTH1 and GPX4, TCN1, and SLC27A6. The FTH1 gene encodes the ferritin protein, which has as a major function the intracellular storage of iron and is often associated with increasing levels during periods of immunological challenge (e.g., disease and inflammation). The GPX4 gene encodes for glutathione peroxidase, a well-known intracellular antioxidant that is essential for embryo development and cell survival (Ran et al., 2007). The TCN1 and $S L C 27 A 6$ genes are perhaps the 2 best examples of this group because of the great fold change observed (TCN1 $=2.53$-fold increase; SLC27A6 $=0.35$-fold decrease). The TCN1 gene encodes a vitamin $\mathrm{B}_{12}$ carrier protein, which delivers this vitamin into cells and is a major compound of secondary granules in neutrophils. The $S L C 27 A 6$ gene encodes a fatty acid transport protein 
for a possible energy source for the cells, especially the rapidly growing conceptus that is being challenged by a systemic proinflammatory state. The direction of the change observed in these 2 genes adds to the challenge on the interpretation of some findings in gene expression observed in this study. Overall, it seems that the LPS challenge causes the endometrium to overexpress some genes in an attempt to correct course for a more ideal environment to receive the conceptus.

The mechanisms related to transport and metabolism are increased during the luteal phase due to the nutrient secretion required for embryonic development (Bauersachs et al., 2008). Once it is involved in regulation of cell growth and differentiation, IGF2 is a growth-promoting hormone during gestation. Geisert et al. (1991) observed increased levels of IGF2 mRNA between 15 and $18 \mathrm{~d}$ of the estrous cycle in pregnant cows compared with cyclic cows, a period that corresponds to rapid conceptus growth. Again, the reason for the upregulation of IGF2 in LPS-treated cows is still unclear. Other growth- and morphogenesis-related genes mostly only tended to be modified in the current experiment, which probably should be interpreted with caution. However, 3 of them $\left(F Z D_{4}, F Z D^{\%}\right.$, and WNT2) were part of the Wnt-signaling cascade pathway and were upregulated in the endometrium of LPStreated cows. The Wnt signaling pathway is implicated in cell polarity, proliferation, differentiation, and junctional complexes (Jamora et al., 2003; Karner et al., 2006) and indicates an important feature of the bovine uterine regulation in preparation to accommodate the conceptus.

One concern when interpreting the results from this study was the low magnitude of several of the genes discussed. More emphasis was placed on key genes with greater fold change, but a few complementary genes with relatively lower fold change were considered important. Other papers, including some by this group (Cerri et al., 2012; Davoodi et al., 2016), have also included genes that had lower differential magnitude. Compared with recent studies that used intrauterine LPS infusion (Lüttgenau et al., 2016) or cows diagnosed with subclinical and clinical endometritis (Salilew-Wondim et al., 2016), the present study observed significantly smaller fold change in the endometrium gene expression. Even in the papers describing uterine disease, genes with lower fold change are also presented. Direct evaluation or induction of uterine disease is expected to generate more robust changes in gene expression caused by direct tissue damage. However, there is little evidence that lower-magnitude differences are meaningless, which makes the reporting of these genes important. Equally important is to recognize the possible limitations of this approach. A step toward improving reliability in future studies is to modify the study design. Although the current experiment was designed with gene expression results in mind, the genes used to calculate the power of the analysis should probably be those previously observed to generate smaller changes.

\section{CONCLUSIONS}

The LPS intramammary infusions triggered an inflammatory response, causing temporary hyperthermia, increased SCC, decreased milk production, and increased serum haptoglobin but no change in CL diameter and concentrations of progesterone before and after AI. Conceptus length and recovery rate were similar between the 2 treatments. On the other hand, LPS treatments caused important changes in the endometrium gene expression at d 15 of gestation. Of the 30 target genes differentially expressed, important ones involved cell adhesion (CADM3, EMMPRIN, SELL, SERPINA14), immune system (PTX3, NFKB, IL6, MUC1), Wnt signaling pathway (FZD4, FZDr, WNT2), and interferon-stimulated (ISG15, MX2, $B M P 15)$ genes. It is noteworthy that some of the directions of the changes observed (up- and downregulation) in these target genes were indeed paradoxical and might indicate a rather compensatory mechanism regulated by the endometrium in an attempt to improve conceptus-endometrium cross-communication.

\section{ACKNOWLEDGMENTS}

We appreciate the financial contribution of the Natural Science and Engineering Research Council (NSERC; Ottawa, ON, Canada), the Higher Education Personnel Improvement Coordination (CAPES; Brasilia, Brazil), National Council for Scientific and Technological Development (CNPq; Brasilia, Brasil), and the University of British Columbia's Dairy Education and Research Centre (Agassiz, BC, Canada). We also thank the students and technicians who assisted in the collection and processing of data.

\section{REFERENCES}

Akira, S., S. Uematsu, and O. Takeuchi. 2006. Pathogen recognition and innate immunity. Cell 124:783-801.

Austin, K. J., S. K. Ward, M. G. Teixeira, V. C. Dean, D. W. Moore, and T. R. Hansen. 1996. Ubiquitin cross-reactive protein is released by the bovine uterus in response to interferon during early pregnancy. Biol. Reprod. 54:600-606.

Barnwell, C. V., P. W. Farin, C. M. Ashwell, W. T. Farmer, S. P. Galphin Jr., and C. E. Farin. 2016. Differences in mRNA populations of short and long bovine conceptuses on day 15 of gestation. Mol. Reprod. Dev. 83:424-441.

Bauersachs, S., K. Mirtko, S. E. Ulbrich, H. Blum, and E. Wolf. 2008. Transcriptome studies of bovine endometrium reveal molecular 
profiles characteristic for specific stages of estrous cycle and early pregnancy. Exp. Clin. Endocrinol. Diabetes 116:371-384.

Bewley, J. M., M. E. Einstein, M. W. Grott, and M. M. Schutz. 2008. Comparison of reticular and rectal core body temperature in lactating dairy cows. J. Dairy Sci. 91:4661-4672.

Bromfield, J. J., J. E. P. Santos, J. Block, R. S. Williams, and I. M. Sheldon. 2015. Uterine infection: Linking infection and innate immunity with infertility in the high-producing dairy cow. J. Anim. Sci. 93:2021-2033.

Burvenich, C., D. D. Bannerman, J. D. Lippolis, L. Peelman, B. J. Nonnecke, M. E. Kehrli Jr., and M. J. Paape. 2007. Cumulative physiological events influence the inflammatory response of the bovine udder to Escherichia coli infections during the transition period. J. Dairy Sci. 90(Suppl. 1):E39-E54.

Cai, T. Q., P. G. Weston, L. A. Lund, B. Brodie, D. J. McKenna, and W. C. Wagner. 1994. Association between neutrophil functions and periparturient disorders in cows. Am. J. Vet. Res. 55:934-943.

Cerri, R. L. A., I. M. Thompson, I. H. Kim, A. D. Ealy, P. J. Hansen, C. R. Staples, J. L. Li, J. E. P. Santos, and W. W. Thatcher. 2012. Effects of lactation and pregnancy on gene expression of endometrium of Holstein cows at day 17 of the estrous cycle or pregnancy. J. Dairy Sci. 95:5657-5675.

Davoodi, S., R. F. Cooke, A. C. Fernandes, B. I. Cappellozza, J. L. M. Vasconcelos, and R. L. A. Cerri. 2016. Expression of estrus modifies the gene expression profile in reproductive tissues on Day 19 of gestation in beef cows. Theriogenology 85:645-655.

Demmers, K. J., K. Derecka, and A. Flint. 2001. Trophoblast interferon and pregnancy. Reproduction 121:41-49.

Eckersall, P. D., F. J. Young, C. McComb, C. J. Hogarth, S. Safi, A Weber, T. McDonald, A. M. Nolan, and J. L. Fitzpatrick. 2001 Acute phase proteins in serum and milk from dairy cows with clinical mastitis. Vet. Rec. 148:35-41.

Edmonson, A. J., I. J. Lean, L. D. Weaver, T. Farver, and G. Webster. 1989. A body condition scoring chart for Holstein dairy cows. J. Dairy Sci. 72:68-78.

Forde, N., F. Carter, T. E. Spencer, F. W. Bazer, O. Sandra, N. Mansouri-Attia, L. A. Okumu, P. A. McGettigan, J. P. Mehta, R. McBride, P. O'Gaora, J. F. Roche, and P. Lonergan. 2011. Conceptusinduced changes in the endometrial transcriptome: How soon does the cow know she is pregnant? Biol. Reprod. 85:144-156.

Geisert, R. D., C. Y. Lee, F. A. Simmen, M. T. Zavy, A. E. Fliss, F. W. Bazer, and R. C. M. Simmen. 1991. Expression of messenger RNAs encoding insulin-like growth factor-I, -II, and insulin-like growth factor binding protein-2 in bovine endometrium during the estrous cycle and early pregnancy. Biol. Reprod. 45:975-983.

Giri, S. N., P. Emau, J. S. Cullor, G. H. Stabenfeldt, M. L. Bruss, R. H. Bondurant, and B. I. Osburn. 1990. Effects of endotoxin infusion on circulating levels of eicosanoids, progesterone, cortisol, glucose and lactic acid, and abortion in pregnant cows. Vet. Microbiol. 21:211-231.

Grummer, R. R., D. G. Mashek, and A. Hayirli. 2004. Dry matter intake and energy balance in the transition period. Vet. Clin. North Am. Food Anim. Pract. 20:447-470.

Hansen. P. J., and C. F. Arechiga. 1999. Strategies for managing reproduction in the heat-stressed dairy cow. J. Anim. Sci. 77:36-50.

Hansen, P. J., P. Soto, and R. P. Natzke. 2004. Mastitis and fertility in cattle - Possible involvement of inflammation or immune activation in embryonic mortality. Am. J. Reprod. Immunol. 51:294-301.

Herath, S., E. J. Williams, S. T. Lilly, R. O. Gilbert, H. Dobson, C. E. Bryant, and I. M. Sheldon. 2007. Ovarian follicular cells have innate immune capabilities that modulate their endocrine function. Reproduction 134:683-693.

Herman, A. P., K. Romanowicz, and D. Tomaszewska-Zaremba. 2010 Effect of LPS on reproductive system at the level of the pituitary of anestrous ewes. Reprod. Domest. Anim. 45:e351-e359.

Hertl, J. A., Y. T. Gröhn, J. D. G. Leach, D. Bar, G. J. Bennett, R. N. González, B. J. Rauch, F. L. Welcome, L. W. Tauer, and Y. H. Schukken. 2010. Effects of clinical mastitis caused by grampositive and gram-negative bacteria and other organisms on the probability of conception in New York State Holstein dairy cows. J. Dairy Sci. 93:1551-1560.
Jackson, J. A., D. E. Shuster, W. J. Silvia, and R. J. Harmon. 1990 Physiological responses to intramammary or intravenous treatment with endotoxin in lactating dairy cows. J. Dairy Sci. 73:627-632.

Jacobsen, S., P. H. Andersen, T. Toelboell, and P. M. H. Heegaard. 2004. Dose dependency and individual variability of the lipopolysaccharide-induced bovine acute phase protein response. J. Dairy Sci. 87:3330-3339

Jamora, C., R. DasGupta, P. Kocieniewski, and E. Fuchs. 2003. Links between signal transduction, transcription and adhesion in epithelial bud development. Nature 422:317-322.

Karner, C.. K. A. Wharton, and T. J. Carroll. 2006. Apical-basal polarity, Wnt signaling and vertebrate organogenesis. Semin. Cell Dev. Biol. 17:214-222

Kim, H., A. A. de Jesus, S. R. Brooks, Y. Liu, Y. Huang, R. VanTries, G. A. Montealegre Sanchez, Y. Rotman, M. Gadina, and R. Goldbach-Mansky. 2018. Development of a validated interferon score using NanoString technology. J. Interferon Cytokine Res. 38:171-185.

Klein, C., S. Bauersachs, S. E. Ulbrich, R. Einspanier, H. H. D. Meyer, S. E. M. Schmidt, H. D. Reichenbach, M. Vermehren, F. Sinowatz, H. Blum, and E. Wolf. 2006. Monozygotic twin model reveals novel embryo-induced transcriptome changes of bovine endometrium in the preattachment period. Biol. Reprod. 74:253-264.

Lavon, Y., G. Leitner, T. Goshen, R. Braw-Tal, S. Jacoby, and D. Wolfenson. 2008. Exposure to endotoxin during estrus alters the timing of ovulation and hormonal concentrations in cows. Theriogenology 70:956-967.

Lüttgenau, J., B. Lingemann, O. Wellnitz, A. K. Hankele, M. Schmicke, S. E. Ulbrich, R. M. Bruckmaier, and H. Bollwein. 2016. Repeated intrauterine infusions of lipopolysaccharide alter gene expression and lifespan of the bovine corpus luteum. J. Dairy Sci. 99:6639-6653.

Makimura, S., and N. Suzuki. 1982. Quantitative determination of bovine serum haptoglobin and its elevation in some inflammatory diseases. Nihon Juigaku Zasshi 44:15-21.

Mishra, B., K. Kizaki, K. Koshi, K. Ushizawa, T. Takahashi, M. Hosoe, T. Sato, A. Ito, and K. Hashizume. 2012. Expression of extracellular matrix metalloproteinase inducer (EMMPRIN) and its expected roles in the bovine endometrium during gestation. Domest. Anim. Endocrinol. 42:63-73.

Miyamoto, Y., D. J. Skarzynski, and K. Okuda. 2000. Is tumor necrosis factor a trigger for the initiation of endometrial prostaglandin $\mathrm{F}_{2 \alpha}$ release at luteolysis in cattle? Biol. Reprod. 62:1109-1115.

Nielsen, B. H., S. Jacobsen, P. H. Andersen, T. A. Niewold, and P. M. H. Heegaard. 2004. Acute phase protein concentrations in serum and milk from healthy cows, cows with clinical mastitis and cows with extramammary inflammatory conditions. Vet. Rec. 154:361365.

NRC. 2001. Nutrient Requirements for Dairy Cattle. Natl. Acad. Sci., Washington, DC

Ran, Q., H. Liang, Y. Ikeno, W. Qi, T. A. Prolla, L. J. Roberts, N. Wolf, H. Van Remmen, and A. Richardson. 2007. Reduction in glutathione peroxidase 4 increases life span through increased sensitivity to apoptosis. J. Gerontol. A Biol. Sci. Med. Sci. 62:932-942.

Ribeiro, E. S., G. Gomes, L. F. Greco, R. L. A. Cerri, A. Vieira-Neto, P. L. J. Monteiro Jr., F. S. Lima, R. S. Bisinotto, W. W. Thatcher, and J. E. P. Santos. 2016. Carryover effect of postpartum inflammatory diseases on developmental biology and fertility in lactating dairy cows. J. Dairy Sci. 99:2201-2220.

Roth, Z., A. Dvir, D. Kalo, Y. Lavon, O. Krifucks, D. Wolfenson, and G. Leitner. 2013. Naturally occurring mastitis disrupts developmental competence of bovine oocytes. J. Dairy Sci. 96:6499-6505.

Salilew-Wondim, D., S. Ibrahim, S. Gebremedhn, D. Tesfaye, M. Heppelmann, H. Bollwein, C. Pfarrer, E. Tholen, C. Neuhoff, K. Schellander, and M. Hoelker. 2016. Clinical and subclinical endometritis induced alterations in bovine endometrial transcriptome and miRNome profile. BMC Genomics 17:218.

Santos, J. E. P., R. L. A. Cerri, M. A. Ballou, G. E. Higginbotham, and J. H. Kirk. 2004. Effect of timing of first clinical mastitis occurrence on lactational and reproductive performance of Holstein dairy cows. Anim. Reprod. Sci. 80:31-45. 
Schrick, F. N., M. E. Hockett, A. M. Saxton, M. J. Lewis, H. H. Dowlen, and S. P. Oliver. 2001. Influence of subclinical mastitis during early lactation on reproductive parameters. J. Dairy Sci. 84:1407-1412.

Sheldon, I. M., A. N. Rycroft, B. Dogan, M. Craven, J. J. Bromfield, A. Chandler, M. H. Roberts, S. B. Price, R. O. Gilbert, and K. W. Simpson. 2010. Specific strains of Escherichia coli are pathogenic for the endometrium of cattle and cause pelvic inflammatory disease in cattle and mice. PLoS One 5:e9192.

Skarnes, R. C., and M. J. K. Harper. 1972. Relationship between endotoxin-induced abortion and the synthesis of prostaglandin $\mathrm{F}$. Prostaglandins 1:191-203.

Skarzynski, D. J., Y. Miyamoto, and K. Okuda. 2000. Production of prostaglandin F2a by cultured bovine endometrial cells in response to tumor necrosis factor $\alpha$ : Cell type specificity and intracellular mechanisms. Biol. Reprod. 62:1116-1120.

Sordillo, L. M., G. M. Pighetti, and M. R. Davis. 1995. Enhanced production of bovine tumor necrosis factor- $\alpha$ during the periparturient period. Vet. Immunol. Immunopathol. 49:263-270.

Soto, P., R. P. Natzke, and P. J. Hansen. 2003. Actions of tumor necrosis factor- $\alpha$ on oocyte maturation and embryonic development in cattle. Am. J. Reprod. Immunol. 50:380-388.
Suzuki, C., K. Yoshioka, S. Iwamura, and H. Hirose. 2001. Endotoxin induces delayed ovulation following endocrine aberration during the proestrous phase in Holstein heifers. Domest. Anim. Endocrinol. 20:267-278.

Ulbrich, S. E., T. Frohlich, K. Schulke, E. Englberger, N. Waldschmidtt, G. J. Arnold, H. D. Reichenbach, M. Reichenbach, E. Wolf, H. H. D. Meyer, and S. Bauersachs. 2009. Evidence for estrogen-dependent uterine serpin (SERPINA14) expression during estrus in the bovine endometrial glandular epithelium and lumen. Biol. Reprod. 81:795-805.

Walker, C. G., S. Meier, M. D. Littlejohn, K. Lehnert, J. R. Roche, and M. D. Mitchell. 2010. Modulation of the maternal immune system by the pre-implantation embryo. BMC Genomics 11:474-487.

Zimov, J. L., N. A. Botheras, W. P. Weiss, and J. S. Hogan. 2011. Associations among behavioral and acute physiologic responses to lipopolysaccharide induced clinical mastitis in lactating dairy cows. Am. J. Vet. Res. 72:620-627. 